\section{Colonial Science}

Science in the British Colonies of America. By Raymond P. Stearns. Pp. $\mathrm{xx}+760$. (University of Illinois: Urbana, Chicago and London, 1970.) $\$ 20$.

By drawing together a mass of well documented material on the activities of natural philosophers in North America from the sixteenth century to the Revolutionary wars, R. P. Stearns has materially extended our knowledge, and his book is a valuable addition to the reference shelf. Firmly based on the manuscript materials relating to the subject in the Bodleian library, the British Museum and the Royal Society, as well as those contained in several American learned institutions, the book combines these with an examination of the printed works of the men whose careers it relates. It thus amply fulfils Stearns's stated objective, the provision of "a comprehensive overview of the scientific interests and activities of American colonials". The approach is largely biographical, short accounts being given of individuals grouped together in geographical regions. Inevitably this makes for somewhat unexciting reading, but Stearns does attempt to pull his work together with introductory and concluding commentaries, and by occasionally standing back to analyse and assess the factual evidence that he presents. In addition to the main text, five sets of "queries", drawn up by the Royal Society in the hope that travellers to America in the 1670 s would bring back answers, are usefully printed in the appendices, together with a checklist of colonial fellows of the Royal Society. A discussion of the location of manuscripts with some indications of areas for future research and a competent index complete the work. Inevitably in a book of this size there are several minor errors. Two which might be corrected in a future edition are the fictitious knighthood conferred on Robert Boyle, and the date of the Musaeum Tradescantium, 1656, not 1658. It should also be noted that there is evidence that this catalogue was largely written by Elias Ashmole and Thomas Wharton in 1652, and not solely by John Tradescant as stated by Stearns.

The usefulness of this book is out of doubt, but of its historical validity one is less certain. Although Stearns acknowledges the foolishness of applying twentieth century criteria of "science" to the seventeenth and eighteenth centuries, he tends none the less to do so and is by so much distanced from his subject matter. Particularly is this true of his treatment of colonial "promotional literature", and of the sixteenth century. Thus the statement "scholars had become so excited in incorporating into the old science [referring primarily to botany and zoology] the new products that captured their notice that they gave too little attention to problems of natural science as a whole" is meaningless because the men to whom Stearns refers had no conception of a dichotomy such as is here postulated, but were carrying out with the new materials such operations as the intellectual and social nexus in which they worked required. Doubts also arise about other parts of Stearns's interpretation. Although he is able to display rather more activity on the part of the Royal Society than might have been expected, his failure to distinguish between the work of the Society as a whole, and the individual efforts of its members, calls into question Stearns's whole reading of the structure of English science in the seventeenth century. Moreover one might question the underlying assumption that natural philosophy in the colonies was, almost by definition, less sophisticated than that in England and Europe. Reading his account one is struck by the similarities displayed with natural philosophy in the English provinces. The complaints of isolation made by a John Winthrop in the New World can be paralleled with those of a John Beale in Somerset (who made proposals to rectify the situation) or the comments of a George Garden in Scotland. Indeed in many ways the colonists attracted more attention, because of the novelties of their environment, than naturalists in the English provinces. Moreover while the Royal Society was prepared to waive colonial subscriptions, the English provincial, who might effectively be as isolated as his colonial counterpart, received no such benefit. Although Stearns insists that American science should be studied in relation to that of England and Europe, he has perhaps not recognized what are the appropriate relations, and has thus exaggerated American isolation during the earlier part of the period. It is unfortunate that at many other points in the argument, similar doubts and objections arise. Valuable though Stearns's work is for reference, it is not a satisfying piece of historical writing.

$$
\text { A. J. TURNER. }
$$

\section{Details of Development}

Lectures on Developmental Physiology. By Alfred Kühn. Translated by Roger Milkman. Pp. $x v+535$. (Springer: Berlin and New York; Universal Book Stall: New Delhi, 1971.) 68 DM; \$21.20.

THE late Alfred Kühn, a distinguished zoologist, published the second and final edition of this book in 1965, and Roger Milkman has performed the Herculean task of translating it into English. It is a set of thirty-six lectures: the first five contain a review of classical cytology; the next five are on the development of lower organisms, including a chapter on fertilization; eleven chapters are on experimental embryology; four chapters are on insect development; four on plant development; two on regeneration, and the concluding five chapters are on a mixture of general principles of development and gene action.

This book is literally what it claims to be: a series of lectures. It is not a tightly constructed book taking a point of view, nor is it an analysis of development. It is a detailed and comprehensive review of selected morphological and experimental studies of the development of a large variety of organisms. The difficulty is that Professor Kühn has done this by writing extensive descriptive passages which make for very hard and certainly dull reading. On the other hand, the 620 illustrations are excellent and tell their story effectively.

As far as I could judge the sections on animal embryology, and especially all the discussion of insect development, are accurate and comprehensive. The parts on plant development are somewhat spotty in their coverage, while the short section on cellular slime moulds is unfortunately full of errors. Another serious problem is that the book is about 10 years old in its content. This means that much of the interesting recent work in many areas is lacking.

Yet despite all these criticisms, this is an impressive book. Many sections will be useful to advanced students; it is a large survey of some of the important work in developmental biology of the first half of this century. The organisms and the experiments he describes must not be forgotten; it is only a pity that their relevance to modern developmental biology has not been made clearer.

\section{J. T. BONNER}

\section{Mites}

The Oribatid Genera of the World. By J. Balogh. Pp. $188+71$ plates. (Akademiai Kiado: Budapest, 1972.) $£ 5$.

ORIBATID mites represent one of the commonest groups of arthropods in soil and leaf litter. More than 130 families and 700 genera have been described and, undoubtedly, many new forms await discovery. During the past decade the rate at which new taxa have been described has surprised even the specialists, and there is an urgent need for the comprehensive taxonomic review now provided by Dr Balogh.

The task that Dr Balogh has set himself is one from which most taxonomists 